\title{
Title: Sampling bias exaggerates a textbook example of a trophic cascade
}

\author{
Authors: Elaine M. Brice ${ }^{1}$, Eric J. Larsen², Daniel R. MacNulty ${ }^{1}$
}

\author{
Affiliations \\ ${ }^{1}$ Department of Wildland Resources and Ecology Center, Utah State University, Logan, UT \\ 84322, USA \\ ${ }^{2}$ Department of Geography and Geology, University of Wisconsin - Stevens Point, Stevens \\ Point, WI 54481, USA \\ *Correspondence to: elbrice92@gmail.com
}

1 Abstract:

2 Understanding how wildland ecosystems respond to the loss and recovery of large

3 predators is vital to decipher the forces that structure food webs and to guide the practice

4 of ecosystem conservation, restoration, and rewilding. This is a major scientific challenge,

5 however, because these large-scale, uncontrolled systems are difficult (or impossible) to sample properly. We show how a tradition of nonrandom sampling has confounded this understanding in a textbook system (Yellowstone National Park) where carnivore [wolf

8 (Canis lupus)] recovery is often associated with a trophic cascade involving changes in

9 herbivore [elk (Cervus canadensis)] behavior and density that promote plant regeneration.

10 Long-term data indicate that a customary practice of sampling only the tallest young plants

11 overestimated regeneration of aspen (Populus tremuloides) by a factor of 3-44 compared to

12 random sampling. Our results demonstrate how seemingly minor departures from

13 principled sampling can generate substantial misunderstandings about the strength of

14 trophic cascades caused by large terrestrial predators. 


\section{Main Text}

18 Much of the empirical information about trophic cascades (indirect effects of predators on plants

19 and abiotic processes) derives from tractable systems that are variously small scale, aquatic,

20 invertebrate, and captive ${ }^{1,2}$. Substantially less is known about trophic cascades in free-living

21 vertebrate communities that span vast landscapes. One reason for this gap is that it is difficult

22 and costly to measure such large, complex, and uncontrolled systems in accordance with

23 fundamental principles of sampling design, including randomization, replication, and control of

24 variation $^{3-5}$. This challenge also means that inference about trophic cascades in large terrestrial

25 ecosystems may be particularly prone to bias.

Concern about sampling bias is a core issue in the longstanding debate about the

27 cascading effects of wolves reintroduced to Yellowstone National Park ${ }^{5-10}$. In this system, the

28 trophic cascade hypothesis is that wolves (Canis lupus) scared away and (or) killed enough elk

29 (Cervus canadensis) to allow various woody deciduous plants (Populus spp., Salix spp.) to

30 recover from decades of unchecked herbivory. A primary support for this hypothesis is time

31 series data showing annual decreases in herbivory and annual increases in plant height following

32 the 1995-1997 wolf reintroduction ${ }^{10-21}$. An inverse relationship between herbivory and plant

33 height is considered critical evidence of a wolf-elk-aspen trophic cascade because it

34 demonstrates the mechanism connecting the lower two trophic levels: reduced herbivory

35 increases plant growth, leading to escape from herbivory if plants grow tall ${ }^{17,19}$. The standard,

36 though untested, assumption is that plants taller than $200 \mathrm{~cm}$ escape the reach of elk and survive

37 to join the overstory. A persistent concern is that reports of decreased herbivory and increased

38 plant height after wolf reintroduction are based on sampling designs that deviate from

39 fundamental principles ${ }^{7-10}$. 
Nonrandom sampling, for example, underpins nearly every annual trend in herbivory and

41 height of young aspen (Populus tremuloides) in Yellowstone National Park that has been

42 credited to a cascading effect of wolves (Extended Data Table 1) ${ }^{10-20}$. In this case, nonrandom

43 sampling involves measuring the three or five tallest young aspen within a stand. The rationale is

44 that the tallest young aspen are "consistently identified", the first to "experience a reduction in

45 browsing pressure", and a "leading edge indication of a broader shift in plant community

46 dynamics"19. An underappreciated problem, however, is that selective sampling of the tallest

47 young aspen may misrepresent trends in the population of young aspen at large. Specifically,

48 nonrandom sampling may have overestimated changes in herbivory and plant height ${ }^{10}$, and thus

49 exaggerated a globally-significant example of a trophic cascade featured in many textbooks ${ }^{22,23}$

50 and popular media ${ }^{24,25}$.

51 We assessed the scope of this potential bias and its implications for understanding trophic

52 cascades in large terrestrial ecosystems with data from a long-term study of young aspen in 113

53 plots distributed across $995-\mathrm{km}^{2}$ of northern Yellowstone National Park (Fig. 1). Each plot was a

$541 \mathrm{~m} \times 20 \mathrm{~m}$ belt transect situated randomly within an aspen stand that was itself randomly

55 selected from an inventory of aspen stands. Herbivory (browsed or unbrowsed) and height of the

56 leader stem (the tallest stem) of every aspen $\leq 600 \mathrm{~cm}$ were measured at the end of the growing

57 season. Herbivory and height of the five tallest stems $\leq 600 \mathrm{~cm}$ growing anywhere within each

58 sampled stand were also measured. Although most plots were measured nearly every year since

$591999^{26}$, we focused on data from 10 years $(2007-2014,2016-2017)$ in which sampled stands

60 included measurements of stems in randomly selected plots ('random stems') and of stems that

61 were the five tallest ('5T stems'). 
Frequency distributions of herbivory levels and heights of 5T stems did not match those

63 of random stems (Fig. 2), confirming that characteristics of the tallest young aspen did not

64 represent those of the general population. Low herbivory levels ( $\leq 20 \%$ stems browsed) and tall

65 heights $(>100 \mathrm{~cm}$ ) were more frequent among 5T stems in 2007 (Fig. 2, A and B), and even

more so in 2017 (Fig. 2, C and D). Assuming the population of random stems was representative

67 of the population of young aspen at large, disparities between the distributions of random and 5T

68 stems indicate that sampling of $5 \mathrm{~T}$ stems yielded biased estimates of average herbivory and stem

69 height.

To test if 5T sampling overestimated annual changes in herbivory and stem height, we

71 pooled measurements of all stems across all years and tested if and how the effect of year on

72 herbivory and stem height varied according to sampling method. We treated the individual stem

73 as the unit of analysis, used generalized linear mixed models (GLMMs) with a binomial error

74 distribution to analyze herbivory as the probability that a stem was browsed, and used linear

75 mixed models with a normal error distribution to analyze log-transformed stem height. All

76 models included random effects for stand identity and year to control for repeated measurements,

77 unmeasured stand-related effects, and stand-specific variation in annual rates of change. To

78 determine the extent that annual changes in herbivory and stem height differed between sampling

79 methods, we tested for an interaction between year and a dummy variable for sampling method.

80 Models with a year $\times$ sampling method interaction fit the data significantly better than did

81 models with only main effects for these variables (herbivory: $\chi_{1}^{2}=134.60, P<0.001$; height: $\chi_{1}^{2}=$

$8249.42, P<0.001)$. The interaction term indicated that annual changes estimated via 5T sampling

83 were 1.3-3.0 times greater than annual changes estimated via random sampling. Specifically,

84 herbivory decreased $23 \% \cdot$ year $^{-1}$ for $5 \mathrm{~T}$ stems $[95 \% \mathrm{CI}=(18 \%, 27 \%), P<0.001]$ versus 
$857 \% \cdot$ year $^{-1}$ for random stems $[95 \% \mathrm{CI}=(2 \%, 13 \%), P=0.007$; Fig. $3 \mathrm{~A}]$, and stem height

86

87 increased $8.6 \% \cdot$ year $^{-1}$ for $5 \mathrm{~T}$ stems $[95 \% \mathrm{CI}=(7.4 \%, 9.8 \%), P<0.001]$ versus $6.7 \% \cdot$ year $^{-1}$ for random stems $[95 \% \mathrm{CI}=(5.6 \%, 7.9 \%), P<0.001$; Fig. 3B $)$.

One reason for these discrepancies was that the sample of 5T stems was dominated by stems that exceeded critical height thresholds beyond which herbivory decreased as stems grew taller; stems below these thresholds were subject to higher levels of herbivory that increased as stems grew taller (Fig. 3C). A confidence set of GLMMs $\left(\Delta \mathrm{AIC}_{\mathrm{c}}<2\right)$ indicated the height threshold was $127-140 \mathrm{~cm}$ for $5 \mathrm{~T}$ stems and 118-129 $\mathrm{cm}$ for random stems (Extended Data Tables, 2, 3). The most parsimonious models in the set indicated that $5 \mathrm{~T}$ stems had a threshold at $132 \mathrm{~cm}$ and random stems at $122 \mathrm{~cm}$, and that each $1-\mathrm{cm}$ increase beyond these thresholds decreased herbivory of $5 \mathrm{~T}$ stems by $2.6 \%(95 \% \mathrm{CI}=2.4 \%, 2.9 \% ; P<0.001)$ and of random stems by $2.2 \%(95 \% \mathrm{CI}=2.1 \%, 2.4 \% ; P<0.001)$. Below these thresholds, each 1 -cm increase in height increased herbivory of random stems by $0.3 \%(95 \% \mathrm{CI}=0.1 \%, 0.4 \% ; P=0.005)$, and of $5 \mathrm{~T}$ stems by $0.2 \%(95 \% \mathrm{CI}=-0.2 \%, 0.7 \% ; P=0.27)$. Stems exceeding the critical height thresholds were 1.6-5.1 times more prevalent in the 5T sample than in the random sample (Fig. 3D).

Another reason 5T sampling estimated a faster rate of height increase compared to random sampling was that $5 \mathrm{~T}$ stems responded more strongly to reduced herbivory than did random stems. This was evident from a linear mixed model of log-transformed stem height fitted to data pooled across the two sampling methods. A model with an interaction between dummy variables for browsing and sampling method outperformed a similar model with only main effects $\left(\chi_{1}^{2}=106.69, P<0.001\right)$. The interaction indicated that the absence of browsing increased height of 5 T stems by $33 \%[95 \% \mathrm{CI}=(29 \%, 36 \%), P<0.001]$ and of random stems by $14 \%$ 
$108 \quad[95 \% \mathrm{CI}=(13 \%, 16 \%), P<0.001$; Fig. 3E $)$. Correlations between annual point estimates of

109 average browse probability (Fig. 3A) and stem height (Fig. 3B) likewise indicated that the

110 inverse relationship between herbivory and stem height was stronger for $5 \mathrm{~T}$ stems $\left(\mathrm{R}^{2}=0.92\right)$

111 than it was for random stems $\left(\mathrm{R}^{2}=0.34\right.$; Fig. $\left.3 \mathrm{~F}\right)$. The tallest stems may have grown taller in the

112 absence of herbivory because they occurred where growing conditions were especially favorable

113 (abundant light, adequate moisture, and more basic soils ${ }^{27,28}$ ). Additionally, because tall stems

114 were browsed less (Fig. 3C), they may have also allocated relatively fewer resources to defense

115 chemistry expression ${ }^{29}$, which would have further accelerated height growth ${ }^{30}$.

116 If we define the cascading effect of wolves on young aspen as the annual percentage of

117 stands with mean stem height exceeding the reach of elk ${ }^{15,16,18,20}, 5 \mathrm{~T}$ sampling combined with a

118 lenient assumption about browse escape height $(>200 \mathrm{~cm})$ estimated an effect 3-44 times greater

119 than that estimated by random sampling with a similar or stricter assumption about browse

120 escape height (>300 cm; Fig. 4). Browse probability of stems $>200 \mathrm{~cm}$ was as high as $0.44(95 \%$

$121 \mathrm{CI}=0.38,0.51)$ for $5 \mathrm{~T}$ stems and $0.32(95 \% \mathrm{CI}=0.24,0.41)$ for random stems, whereas browse

122 probability of all stems $>300 \mathrm{~cm}$ was nearly zero $(\leq 0.05$; Fig. $3 \mathrm{C})$.

123 Although 5T sampling grossly overestimated the average increase in aspen regeneration

124 following wolf reintroduction, it correctly showed that an increase was underway. Nevertheless,

125 even the more modest increase shown by random sampling cannot be attributed to wolves alone.

126 This is because wolves were not the sole cause of the elk population decline $\mathrm{e}^{10,31}$, and there is

127 scant evidence that they frightened elk away from aspen or any other habitat ${ }^{32,33}$. A weak

128 cascading effect of wolves is consistent with theory that predicts little or no such effect in food

129 webs like northern Yellowstone that feature resource limitation, reticulation (trophic levels with

130 multiple species with similar resource requirements), and environmental heterogeneity (4). 
132 urgent by the rapid pace of global environmental change, including the extirpation and recovery

133 of large carnivorous land mammals ${ }^{34,35}$. Our results demonstrate how deviations from basic

134 sampling principles can distort this understanding. Nonrandom sampling overestimated the

135 strength of a hypothesized trophic cascade in the system we studied, but it may underestimate

136 cascading effects in other systems. In observational studies of large terrestrial ecosystems that

137 lack control, randomization is an essential guard against unreliable inferences and the misguided

138 policy and management decisions they may spawn. Fidelity to principled sampling is also vital to

139 address growing concern about the reliability of many scientific findings ${ }^{36,37}$. 


\section{References}

142 1. Piovia-Scott, J., Yang, L. H. \& Wright, A. N. Temporal variation in trophic cascades. Annual

143 Review of Ecology, Evolution, and Systematics 48, 281-300 (2017).

144 2. Alston, J. M. et al. Reciprocity in restoration ecology: When might large carnivore

145 reintroduction restore ecosystems? Biological Conservation 234, 82-89 (2019).

146 3. Ford, A. T. \& Goheen, J. R. Trophic cascades by large carnivores: A case for strong

147 inference and mechanism. Trends in Ecology \& Evolution 30, 725-735 (2015).

148 4. Allen, B. L. et al. Can we save large carnivores without losing large carnivore science? Food

$149 \quad$ Webs 12, 64-75 (2017).

150 5. Hayward, M. W., Edwards, S., Fancourt, B. A., Linnell, J. D. C. \& Nilsen, E. B. Top-down

151 control of ecosystems and the case for rewilding: does it all add up? in Rewilding (eds.

152 Pettorelli, N., Durant, S. M. \& du Toit, J. T.) 325-354 (Cambridge University Press, 2019).

153 6. Bilyeu, D. M., Cooper, D. J. \& Hobbs, N. T. Water tables constrain height recovery of

154 willow on Yellowstone's northern range. Ecological Applications 18, 80-92 (2008).

155 7. Kauffman, M. J., Brodie, J. F. \& Jules, E. S. Are wolves saving Yellowstone's aspen? A

156 landscape-level test of a behaviorally mediated trophic cascade: reply. Ecology 94, 1425-

$157 \quad 1431(2013)$.

158 8. Winnie, J. Predation risk, elk, and aspen: reply. Ecology 95, 2671-2674 (2014).

159 9. Fleming, P. J. S. They might be right, but Beschta et al. (2018) give no strong evidence that

160 "trophic cascades shape recovery of young aspen in Yellowstone National Park": A

161 fundamental critique of methods. Forest Ecology and Management 454, 117283 (2019). 
162 10. Peterson, R. O., Vucetich, J. A., Bump, J. M. \& Smith, D. W. Trophic cascades in a multicausal world: Isle Royale and Yellowstone. Annual Review of Ecology, Evolution, and Systematics 45, 325-345 (2014).

11. Ripple, W. J. \& Beschta, R. L. Restoring Yellowstone's aspen with wolves. Biological Conservation 138, 514-519 (2007).

167 12. Halofsky, J. S., Ripple, W. J. \& Beschta, R. L. Recoupling fire and aspen recruitment after wolf reintroduction in Yellowstone National Park, USA. Forest Ecology and Management 256, 1004-1008 (2008).

13. Beschta, R. L. \& Ripple, W. J. Large predators and trophic cascades in terrestrial ecosystems

14. Ripple, W. J. \& Beschta, R. L. Trophic cascades in Yellowstone: The first 15 years after wolf reintroduction. Biological Conservation 145, 205-213 (2012).

174 15. Painter, L. E., Beschta, R. L., Larsen, E. J. \& Ripple, W. J. After long-term decline, are aspen recovering in northern Yellowstone? Forest Ecology and Management 329, 108-117 (2014).

177 16. Painter, L. E., Beschta, R. L., Larsen, E. J. \& Ripple, W. J. Recovering aspen follow changing elk dynamics in Yellowstone: evidence of a trophic cascade? Ecology 96, 252-263

180 17. Beschta, R. L. \& Ripple, W. J. Riparian vegetation recovery in Yellowstone: The first two 181 decades after wolf reintroduction. Biological Conservation 198, 93-103 (2016).

182 18. Beschta, R. L., Painter, L. E., Levi, T. \& Ripple, W. J. Long-term aspen dynamics, trophic 183 cascades, and climate in northern Yellowstone National Park. Canadian Journal of Forest $184 \quad$ Research 46, 548-556 (2016). 
19. Beschta, R. L., Painter, L. E. \& Ripple, W. J. Trophic cascades at multiple spatial scales shape recovery of young aspen in Yellowstone. Forest Ecology and Management 413, 62-69 (2018).

20. Painter, L. E., Beschta, R. L., Larsen, E. J. \& Ripple, W. J. Aspen recruitment in the Yellowstone region linked to reduced herbivory after large carnivore restoration. Ecosphere 9, $\mathrm{e} 02376(2018)$.

21. Runyon, M. J., Tyers, D. B., Sowell, B. F. \& Gower, C. N. Aspen restoration using beaver on the northern Yellowstone winter range under reduced ungulate herbivory. Restoration Ecology 22, 555-561 (2014).

22. Boyce, M. S., Merrill, E. H. \& Sinclair, A. R. E. Wildlife Management. in The Princeton Guide to Ecology (eds. Levin, S. A., Carpenter, S. R. \& Godfray, H. C. J.) (Princeton

23. Chapin, F. S., Matson, P. A. \& Vitousek, P. M. Principles of Terrestrial Ecosystem Ecology. (Springer, 2011).

24. Monbiot, G. How wolves change rivers. (2014).

200 25. Morell, V. Aspens return to Yellowstone, with help from some wolves. Science 317, 438439 (2007).

26. Ripple, W. J., Larsen, E. J., Renkin, R. A. \& Smith, D. W. Trophic cascades among wolves, elk and aspen on Yellowstone National Park's northern range. Biological conservation 102, $227-234$ (2001). aspen dynamics in the Greater Yellowstone Ecosystem. Landscape Ecology 21, 933-951 (2006). 
28. Hansen, W. D., Romme, W. H., Ba, A. \& Turner, M. G. Shifting ecological filters mediate postfire expansion of seedling aspen (Populus tremuloides) in Yellowstone. Forest Ecology and Management 362, 218-230 (2016).

29. Rhodes, A. C., Anderson, V. \& St Clair, S. B. Ungulate herbivory alters leaf functional traits and recruitment of regenerating aspen. Tree Physiol 37, 402-413 (2017).

30. Lindroth, R. L. \& St. Clair, S. B. Adaptations of quaking aspen (Populus tremuloides Michx.) for defense against herbivores. Forest Ecology and Management 299, 14-21 (2013).

215 31. Vucetich, J. A., Smith, D. W. \& Stahler, D. R. Influence of harvest, climate and wolf 216 predation on Yellowstone elk, 1961-2004. Oikos 111, 259-270 (2005).

32. Kohl, M. T. et al. Diel predator activity drives a dynamic landscape of fear. Ecological Monographs 88, 638-652 (2018).

33. Cusack, J. J. et al. Weak spatiotemporal response of prey to predation risk in a freely interacting system. Journal of Animal Ecology 89, 120-131 (2019).

35. Atkins, J. L. et al. Cascading impacts of large-carnivore extirpation in an African ecosystem.

36. Forstmeier, W., Wagenmakers, E.-J. \& Parker, T. H. Detecting and avoiding likely falseScience 364, 173-177 (2019). positive findings - a practical guide. Biological Reviews 92, 1941-1968 (2017).

37. Fraser, H., Parker, T., Nakagawa, S., Barnett, A. \& Fidler, F. Questionable research practices in ecology and evolution. PLOS ONE 13, e0200303 (2018). 
- Sampling Plots

- Roads

Northern Yellowstone elk winter range

- Yellowstone National Park

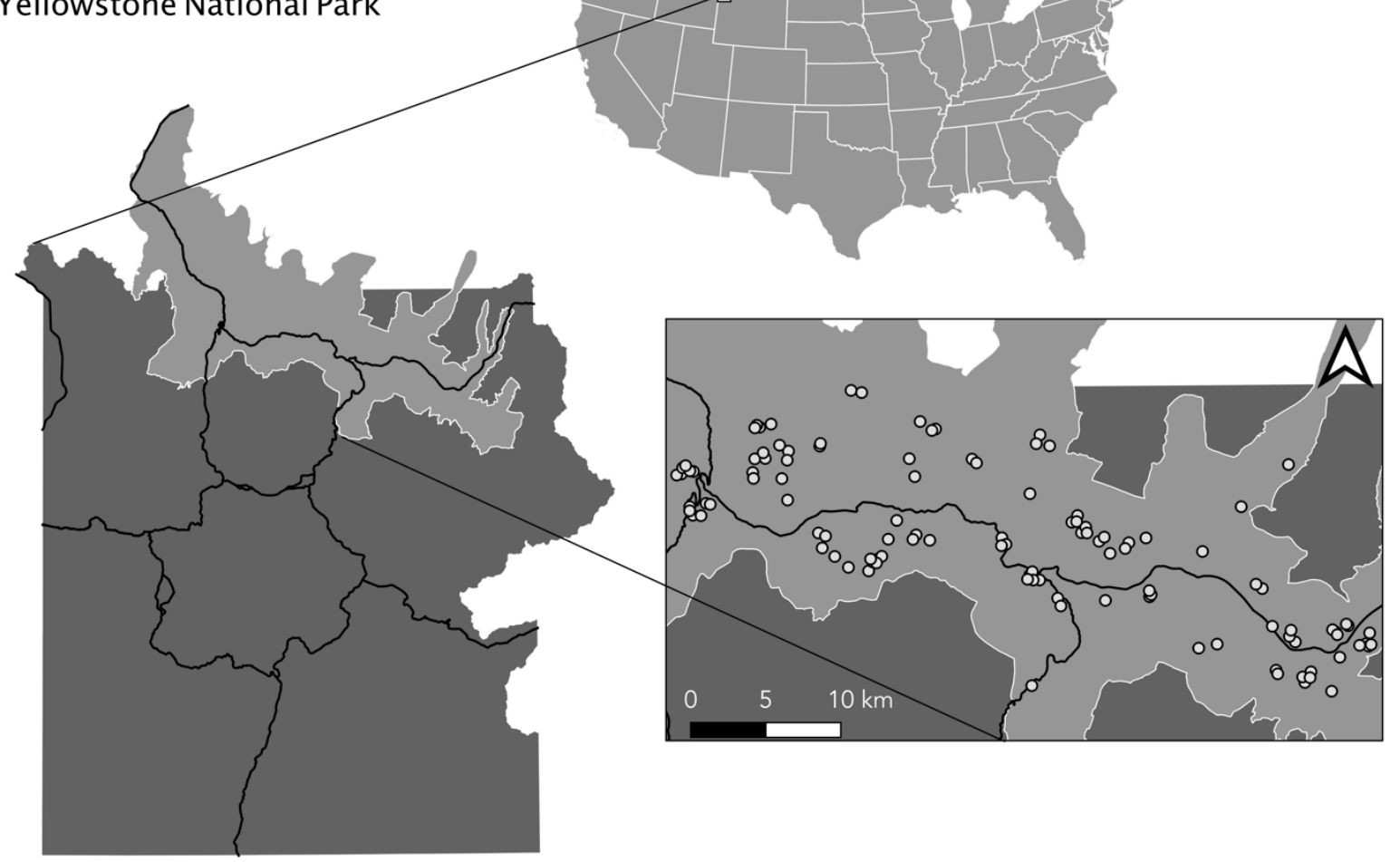

Fig. 1. Location of sampled aspen stands. The northern Yellowstone elk winter range is the maximum distribution of the northern Yellowstone elk population during winter when elk often browse young aspen. 

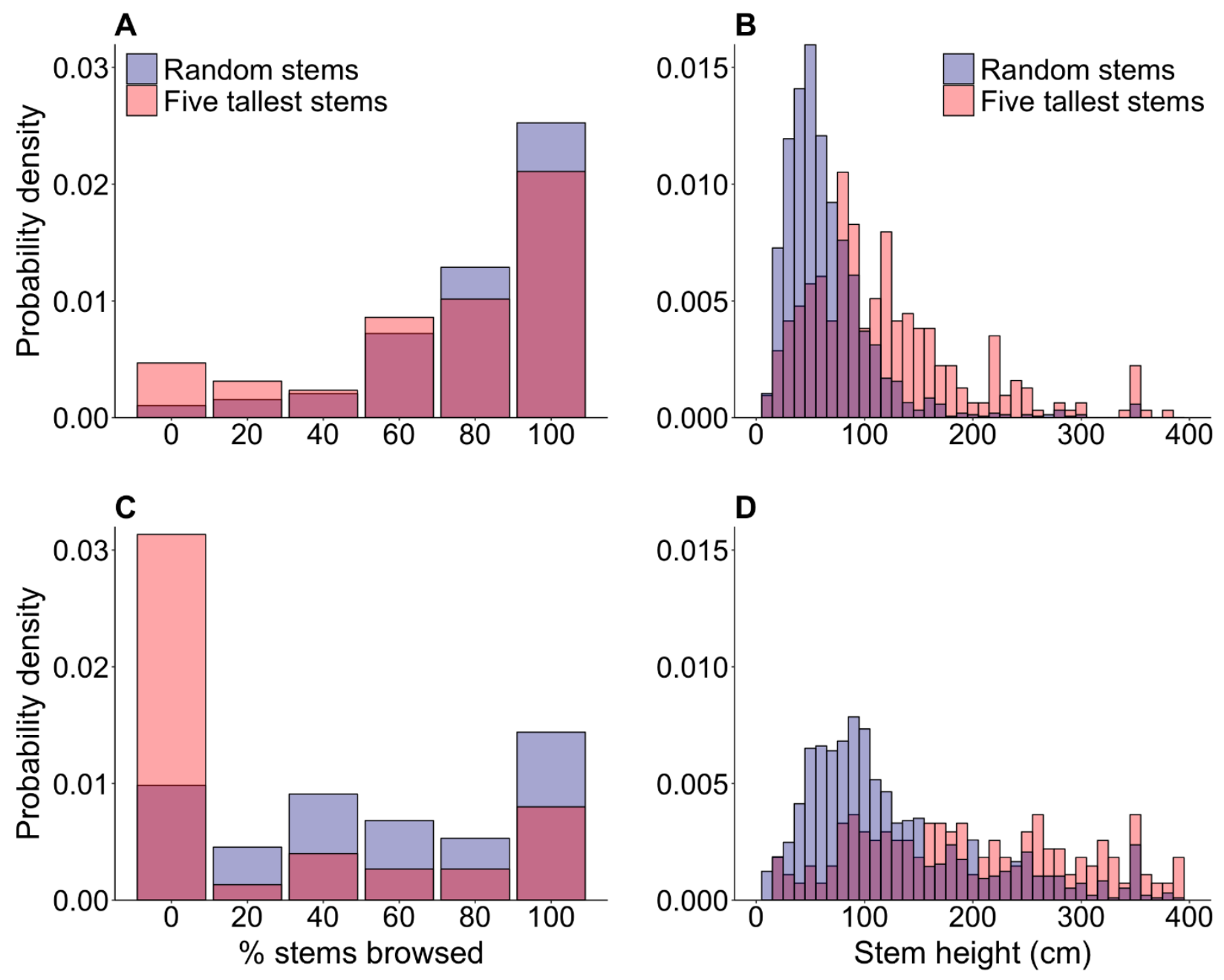

Fig. 2. Selective sampling of the five tallest young aspen describe distributions of herbivory levels and stems heights that differ from distributions estimated by random sampling. Low herbivory levels (A and $\mathbf{C})$ and tall heights (B and $\mathbf{D})$ were more characteristic of the five tallest young aspen throughout the study from 2007 (A and B) to 2017 (C and D). 

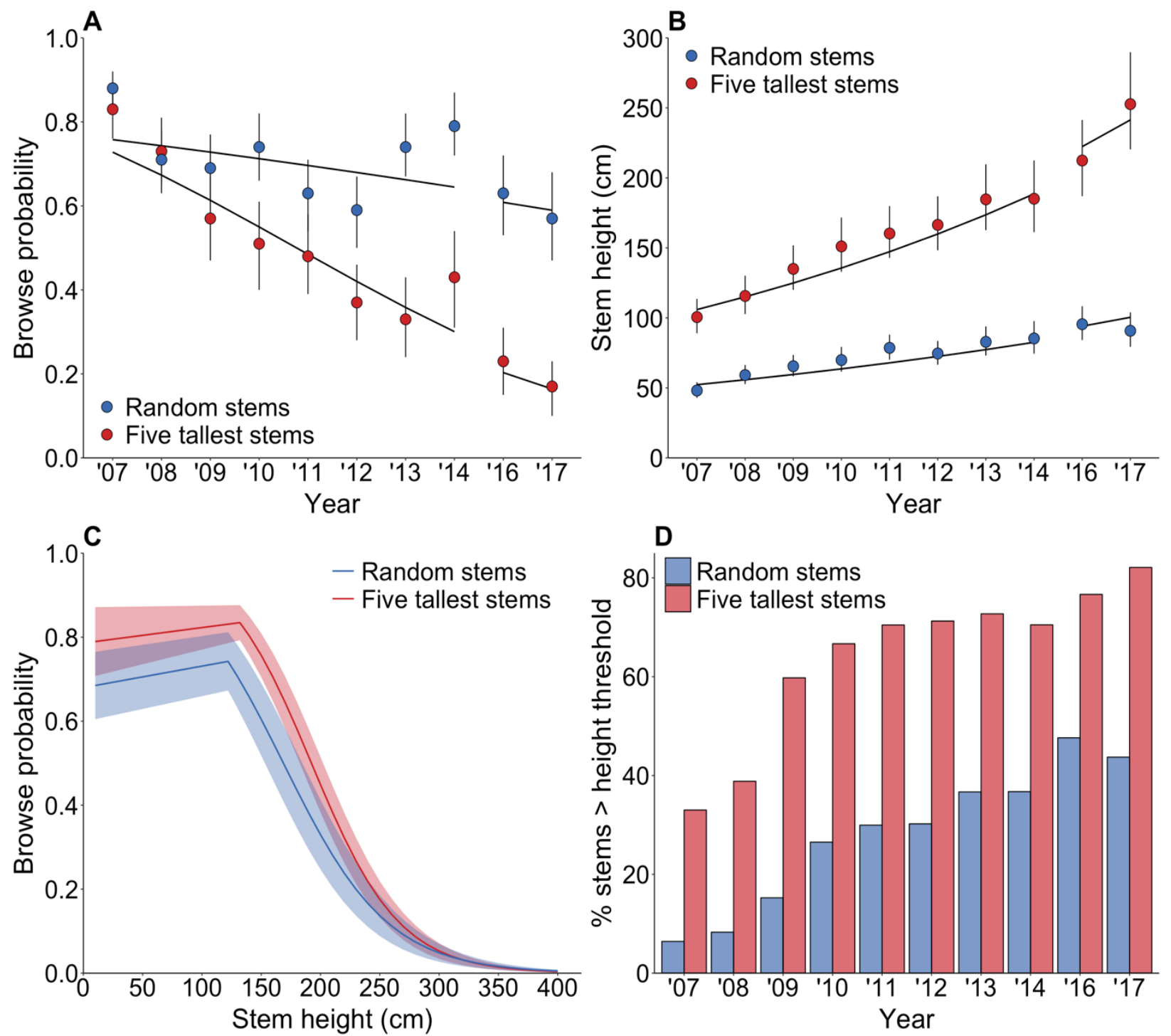

D
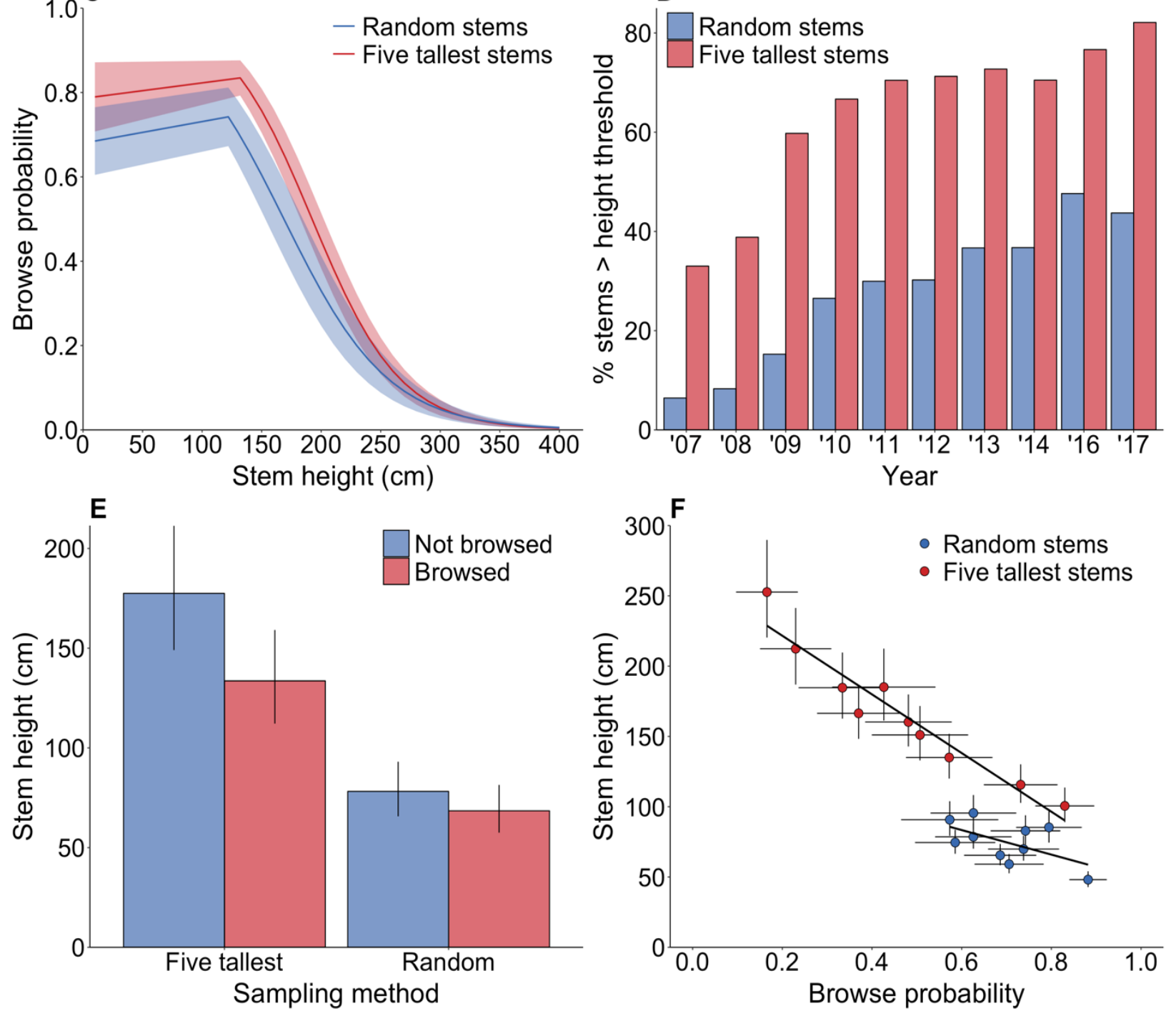
Fig 3. Effects of nonrandom sampling on estimates of herbivory and height of young aspen.

(A) Relative to a random sample, a nonrandom sample of the five tallest stems estimated a faster decrease in herbivory, and a (B) faster increase in stem height that were explained by how (C) stems exceeding critical height thresholds beyond which herbivory decreased were (D) more prevalent in the nonrandom sample $(\mathrm{N}=317-518$ per year) than in the random sample $(\mathrm{N}=1027$ 1748 per year), and by how ( $\mathbf{E}$ and $\mathbf{F})$ stems in the nonrandom sample responded more strongly to reduced herbivory than did those in the random sample. Results in (A)-(C) and (E)-(F) are population-averaged fitted values with $95 \%$ confidence intervals from best-fit models. 


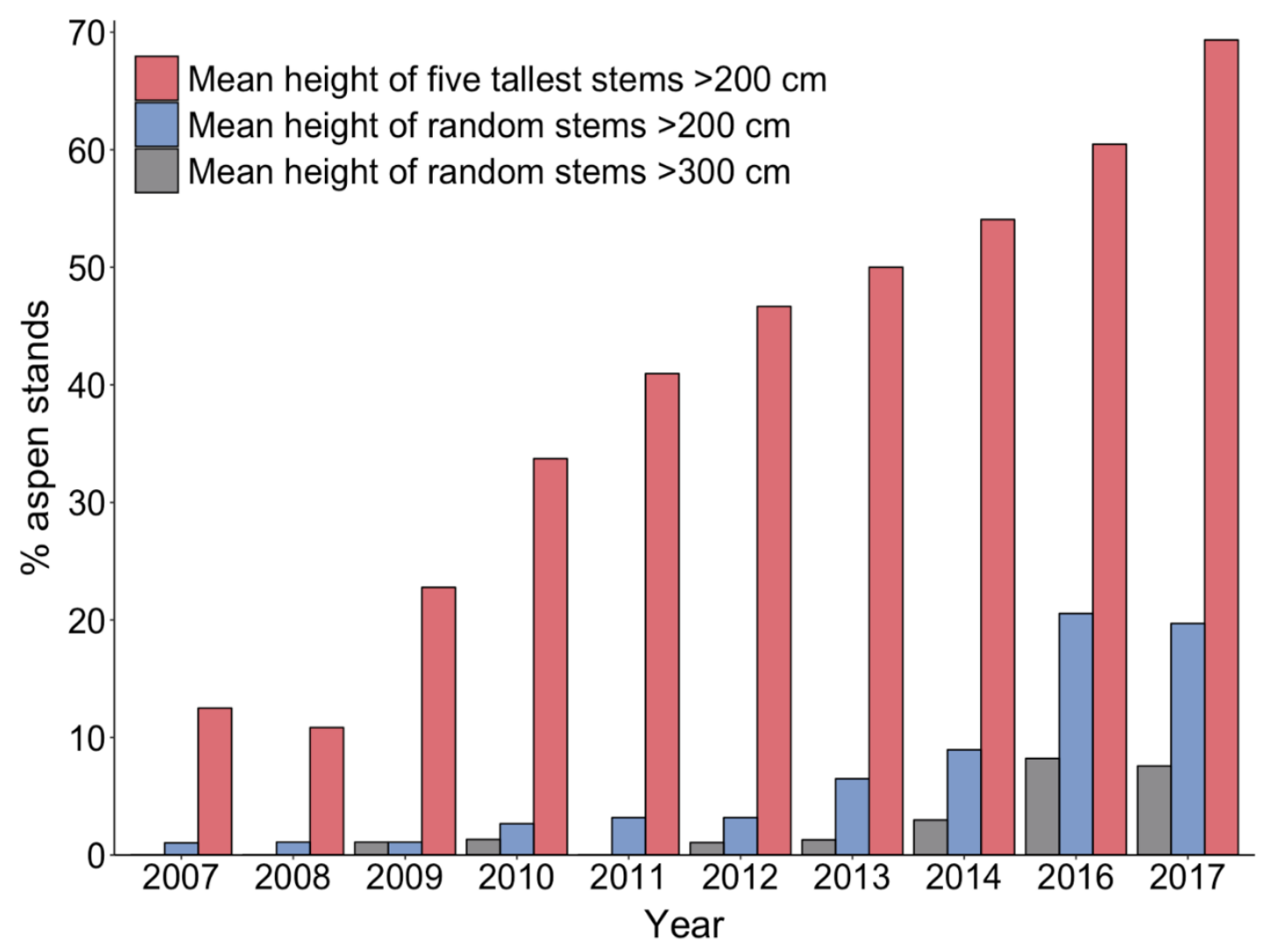

Fig. 4. Effect of nonrandom sampling on estimates of regeneration of overstory aspen

stems. Bars indicate the annual percentage of sampled aspen stands in which the mean height of the five tallest stems and randomly sampled stems exceeded a presumed browse-escape height of $200-\mathrm{cm}$ or $300-\mathrm{cm}$. No stands had a mean height of random stems $>300-\mathrm{cm}$ in 2007,2008 , and 2011. 


\section{Methods}

\section{Study area}

234 We measured aspen within the portion of the northern Yellowstone elk winter range that lies

235 within Yellowstone National Park (Fig. 1). This $995-\mathrm{km}^{2}$ area is defined by the low-elevation

236 (2000-2600 m) grasslands and shrub steppes that fan out from the Yellowstone River and its

237 tributaries near the Park's northern border. Sagebrush steppe (mainly big sagebrush [Artemisia

238 tridentata]), Idaho fescue [Festuca idahoensis], and blue-bunch wheatgrass [Pseudoroegneria

239 spicata]) is the dominant plant community at lower elevations, with conifer forests (mainly

240 Douglas fir [Pseudotsuga menziesii] and lodgepole pine [Pinus contorta]) at higher elevations.

241 Aspen (Populus tremuloides) are scattered in discrete stands on relatively moist mid-elevation

242 benches, near streams, and along conifer forest/shrub steppe ecotones ${ }^{38}$.

243 Low elevations in the study area create the warmest and driest conditions in the Park,

244 providing important winter range for ungulates, including elk (Cervus canadensis), bison (Bison

245 bison), mule deer (Odocoileus hemionus), moose (Alces alces), and bighorn sheep (Ovis

246 canadensis). Elk have been the most abundant ungulate species in the study area for most of the

247 time since Park establishment in $1872^{38}$, reaching an estimated 17,740 individuals during winter

248 1994-1995 ${ }^{39}$. Subsequent decreases in elk numbers and increases in bison numbers led bison to

249 overtake elk as the most numerous ungulate in the study area beginning winter 2011-2012. From

250 winter 1995-1996 to winter 2014-2015, elk numbers decreased from 15,913 to 1,853, whereas

251 bison numbers increased from 681 to 2,164. During this same period, estimated numbers of elk

252 in the winter range outside the Park varied between 2,449 and 5,147, and annually exceeded

253 those inside the Park beginning winter 2011-2012 ${ }^{39}$. Approximate numbers of elk and bison 
254 wintering in the study area during each year of our study (2007-2017) ranged from 1,200-6,000

255 elk and 1,400-3,200 bison.

256 Wolves were reintroduced to Yellowstone National Park in 1995-199740 and their annual

257 distribution has been concentrated in the study area ${ }^{41}$. Other large carnivores in the study area

258 included cougar (Puma concolor), brown bear (Ursus arctos), and black bear (Ursus

259 americanus). All four predators preyed on elk, with bears killing mainly calves ${ }^{42}$, and cougars

260 and wolves killing calves and adults ${ }^{43,44}$. Elk that moved beyond the study area into adjacent

261 areas of Montana were also subject to predation from human hunters regulated by Montana Fish,

262 Wildlife, and Parks ${ }^{45}$. Humans were the only significant predator of bison, and this included

263 management removals at the Park boundary, as well as regulated hunting in adjacent areas of

264 Montana $^{46}$.

266 Study population

267 Aspen is the most widely distributed native tree species in North America and one of the few

268 upland deciduous tree species in Yellowstone National Park. It is a clonal species that mainly

269 regenerates by root sprouting with occasional seedling establishment after fire and other

270 disturbances. Root sprouting produces genetically identical trees from a common root system

271 that may be substantially older than the age of the oldest tree, which is rarely more than 150

272 years. Aspen requires moist soils and occurs mostly in areas with at least $38 \mathrm{~cm}$ of annual

273 precipitation ${ }^{47}$; the study area is near this lower $\operatorname{limit}^{48}$. Although aspen is a minor cover type in

274 the arid portions of its range, it is a major source of biological diversity, providing habitat for

275 numerous plants and animals ${ }^{49,50}$. Various ungulate species, for example, eat the leaders and

276 twigs of young aspen stems, especially during winter. Persistent herbivory of a stem's leader 
277 prevents its growth to tree height, a process that has contributed to loss of overstory aspen in 278 parts of western North America, including the study area ${ }^{51,52}$.

$279 \quad$ Historic landscape photographs suggest that overstory aspen covered approximately 4-

$2806 \%$ of the study area during $1880-1900^{38,53}$. Aerial photographs indicate that aspen coverage

281 decreased to $2-3 \%$ in the $1970 \mathrm{~s}^{38}$ and to as little as $1 \%$ in the $1990 \mathrm{~s}^{54}$. Poor regeneration of tree-

282 sized aspen was noted in the study area as early as the 1920s and attributed to herbivory from

283 beaver $^{55}$ and elk ${ }^{56,57}$. As beaver abundance declined ${ }^{58}$ and elk abundance remained high ${ }^{38}$,

284 subsequent observers emphasized the role of elk herbivory in preventing aspen regeneration,

285 with some considering it a proximal factor, secondary to fire suppression and climate

286 variation ${ }^{38,59,60}$, and others judging it an ultimate factor ${ }^{51,61,62}$. Romme et al. ${ }^{63}$ concluded that the

287 dearth of aspen regeneration was not the work of any single factor, but involved the combined

288 action of multiple factors including fire suppression, drying climate, and high levels of elk

289 herbivory possibly linked to the extirpation of wolves.

290 Studies conducted in advance of wolf reintroduction did not predict any cascading effects

291 of wolves on aspen or other plant species $^{59}$. Nevertheless, subsequent research proposed that

292 regeneration of tree-sized aspen is a necessary function of wolves reducing elk herbivory ${ }^{64,65}$.

293 Consistent with this hypothesis, the first evidence of substantial numbers of unprotected aspen

294 reaching tree height since the early- to mid- $20^{\text {th }}$ century ${ }^{7,48}$ occurred about a decade after wolf

295 reintroduction ${ }^{11}$. Although this pattern favors future increases in overstory aspen, climate

296 warming is expected to reduce suitable habitat for aspen in the study area within the next 40-80

297 years $^{66}$.

298

299 Data collection 
We measured herbivory and height of young aspen in 113 plots distributed randomly across the study area (Fig. 1). Each plot was a $1 \mathrm{~m} \times 20 \mathrm{~m}$ belt transect set randomly within an aspen stand that was itself randomly selected from an inventory of aspen stands. The inventory was a list of

303992 landscape grid cells $(240 \mathrm{~m} \times 360 \mathrm{~m})$ across the study area that contained at least one aspen

304 stand. A "stand" was a group of tree-size aspen in which each tree was $\leq 30 \mathrm{~m}$ from every other

305 tree. Aspen stands were identified from 83 color infrared aerial photographs $(1: 24,000)$ taken in

306 October 1988 . To identify stands, a $1.0 \mathrm{~cm} \times 1.5 \mathrm{~cm}$ grid of 96 cells $(240 \mathrm{~m} \times 360 \mathrm{~m}$ ground

307 dimensions) was overlain on each photograph, and a scanning stereoscope was used to identify

308 all cells containing at least one aspen stand. In these aerial photographs, aspen were identifiable

309 as white crowns, whereas conifers appeared as red crowns ${ }^{48}$. One hundred and thirteen grid cells

310 were randomly selected from the inventory (11\% of 992 cells), one aspen stand was randomly

311 selected from each cell, and one plot was established in each stand, with the start point and

312 transect direction randomly determined ${ }^{26}$.

313 We measured aspen at the end of the growing season from late July to September,

314 focusing on plants that were $\leq 600 \mathrm{~cm}$ tall, which we term "young aspen". For each aspen stand,

315 we measured every young aspen rooted within a plot ('random stems'), as well as each of the

316 five tallest young aspen rooted within the stand ('5T stems'). For each type of young aspen, we

317 measured herbivory (browsed or unbrowsed) and height of the leader stem (the tallest stem). A

318 leader was considered 'browsed' if its growth from the previous growing season had been eaten.

\section{$320 \quad$ Statistics}

321 First, we examined frequency distributions of herbivory levels and heights of random stems and

$3225 \mathrm{~T}$ stems for the first and last years of the study $(2007,2017)$ to visualize the extent that 
323 characteristics of the tallest young aspen represented those of the general population. To do so, we

324 calculated probability densities of herbivory levels and stem heights using kernel density

325 estimation with a Gaussian distribution scaled to integrate to one. Separate probability densities

326 were calculated for random stems and 5T stems for each year. Individual stands and plots were the

327 units of analysis in the probability densities of herbivory, with stands pertaining to 5T stems and

328 plots pertaining to random stems. Herbivory of 5T stems equaled the percentage of the five tallest

329 stems within a stand that were browsed, providing one of six possible values: $0 \%, 20 \%, 40 \%, 60 \%$,

$33080 \%$, and $100 \%$. Herbivory of random stems was the percentage of young stems within a plot that

331 were browsed, and we rounded these values to the nearest of the preceding percentages to enable

332 comparison with 5T stems (Fig. 2, A and C; 2007: $\mathrm{N}_{5 \mathrm{~T}}=64$ stands, $\mathrm{N}_{\text {Random }}=97$ plots; 2017: $\mathrm{N}_{5 \mathrm{~T}}$

$333=75$ stands, $\mathrm{N}_{\text {Random }}=66$ plots). Sample sizes were less than 113 in these data because some

334 stands/plots were not sampled or contained no young stems. The individual stem was the unit of

335 analysis in the probability densities of height, with individual heights pooled across stands and

336 plots for each year (Fig. 2, B and D; 2007: $\mathrm{N}_{\text {random }}=369, \mathrm{~N}_{5 \mathrm{~T}}=315 ; 2017: \mathrm{N}_{\text {random }}=1027, \mathrm{~N}_{5 \mathrm{~T}}=$

337 1540).

338 Second, we used mixed-effects models to analyze how selective sampling of 5T stems

339 influenced estimates of annual changes in herbivory (stem-level probability of browsing) and

340 stem height. To do so, we combined measurements of 5T stems and random stems into a single

341 dataset of all stems $(\mathrm{N}=18,623)$ across all years $(\mathrm{N}=10$ years; 2007-2014, 2016-2017), and

342 tested how the effect of year on herbivory and height of individual stems differed by sampling

343 method. Specifically, we treated the individual stem as the unit of analysis and tested for an

344 interactive effect of year and sampling method on (a) whether a stem was browsed, and (b)

345 height of the stem. Year was an integer that ranged from 1 (2007) to 11 (2017), and sampling 
method was a dummy variable $(1=5 \mathrm{~T}$ sampling; $0=$ random sampling $)$. We analyzed models with year specified as a continuous or categorical variable.

Models included a random intercept for stand identity and a random slope for year, which

349 permitted stand-specific trends in herbivory and stem height. The random intercept also

350 controlled for correlation among measurements of the same stand in multiple years and

351 unmeasured stand-related effects including soil, water, and light conditions. We used logistic

352 regression to analyze the probability a stem was browsed $(1=$ browsed; $0=$ not browsed $)$, and

353 linear regression to analyze stem height $(\mathrm{cm})$. We log-transformed stem heights prior to analysis

354 to ensure that model residuals approximated a normal distribution. Fitted values from models of

355 stem height were back-transformed to the linear scale to facilitate interpretation.

356 To test how 5T sampling affected estimates of annual changes in herbivory and stem

357 height, we used likelihood ratio tests to compare models with and without a year $\times$ sampling

358 method interaction. Models including this interaction outperformed those that did not regardless

359 of whether the effect of year was treated as continuous (herbivory: $\chi_{1}^{2}=134.60, P<0.001$;

360 height: $\chi_{1}^{2}=49.42, P<0.001$ ) or categorical (herbivory: $\chi_{9}^{2}=170.03, P<0.001$; height: $\chi_{9}^{2}=$

361 144.12, $P<0.001$ ). We calculated population-averaged fitted values of herbivory (Fig. 3A) and

362 stem height (Fig. 3B) from the interaction models by deriving marginal expectations of the

363 responses averaged over the random effects but conditional on the observed variables. We used

364 models including the continuous year $\times$ sampling method interaction to calculate and compare

365 annual changes estimated via 5T sampling and random sampling. Annual decrease in herbivory

366 equaled one minus the odds ratio for the effect of year on the probability of browsing,

367 conditional on the sampling method. Annual increase in stem height equaled $\left[\left(e^{\beta}\right)-1\right] \times 100$ 
where $\beta$ was the coefficient estimate for the continuous effect of year on stem height conditional on sampling method.

Third, we quantified the influence of stem height on browse probability to identify the

371 height at which stems escaped herbivory. Using mixed-effects logistic regression models, we

372 analyzed stem heights on a linear scale and estimated separate models for $5 \mathrm{~T}$ stems $(\mathrm{N}=4,265)$

373 and random stems $(\mathrm{N}=14,358)$. Models specified stand identity and year as crossed random

374 intercepts, such that the random intercept for stand $i$ was shared across all years for a given stand

$375 i$, whereas the random intercept for year $j$ was shared by all stands in a given year $j$. This random

376 effects structure accounted for correlation between measurements taken on the same stand in

377 multiple years and on multiple stands in the same year. It also accounted for unmeasured stand-

378 and year-related effects.

379 We used piecewise linear splines to identify the threshold stem height beyond which the

380 probability of browsing decreased. To determine the presence and position of height-specific

381 thresholds, we evaluated separate sets of competing models for 5T and random stems. Each

382 model set included models with a single knot placed from $10-200 \mathrm{~cm}$ at $1 \mathrm{~cm}$ or $10 \mathrm{~cm}$ intervals,

383 a model with no knot representing the hypothesis of no threshold in browsing, and an intercept-

384 only model representing the null hypothesis that stem height had no effect on browsing

385 (Extended Data Tables 2, 3). A knot was the join point between two linear splines. We selected

386 knots a priori based on the standard assumption that aspen stems taller than $200 \mathrm{~cm}$ escape

387 herbivory and join the overstory ${ }^{61}$. Our placement of knots was consistent with guidelines for the 388 efficient use of knots ${ }^{67,68}$. By definition, knots selected a priori are fixed (i.e., not random 389 variables) and are therefore not estimated as parameters in models. We constructed variables 
containing a linear spline for stem height so that the estimated coefficients measure the slopes of

391 the segments before and after a given knot.

We evaluated competing models using information-theoretic statistics ${ }^{69}$. Our scope of

393 inference concerned the population, so we performed model selection using marginal

394 likelihoods. The most parsimonious model was the one with the lowest Akaike Information

395 Criterion (adjusted for small sample, $\mathrm{AIC}_{\mathrm{c}}$ ) and smallest $\Delta \mathrm{AIC}_{\mathrm{c}} . \Delta \mathrm{AIC}_{\mathrm{c}}$ equals the $\mathrm{AIC}_{\mathrm{c}}$ for the 396 model of interest minus the smallest $\mathrm{AIC}_{\mathrm{c}}$ for the set of models being considered. The best model

397 has a $\Delta \mathrm{AIC}_{\mathrm{c}}$ of zero, and models with $\Delta \mathrm{AIC}_{\mathrm{c}}<2$ are plausibly the best. To assess uncertainty

398 about the best model, we identified models with $\Delta \mathrm{AIC}_{\mathrm{c}}<2$ as the confidence set of models

399 (analogous to a confidence interval for a mean estimate ${ }^{69}$; Extended Data Tables 2, 3). We used

400 odds ratios from the best models to estimate how the probability of browsing changed with

401 increasing stem height, and calculated population-averaged fitted values from these models (Fig.

$4023 \mathrm{C}$ ) as described above. We also calculated the proportion of stems in each annual sample of 5T

403 and random stems that exceeded the height thresholds identified in the best models (Fig. 3D).

Fourth, we analyzed how selective sampling of 5T stems influenced estimates of the

405 effect of herbivory on stem height. Recall that a strong negative effect of herbivory on stem

406 height is considered critical evidence of a wolf-elk-aspen trophic cascade because it

407 demonstrates the mechanism connecting the lower two trophic levels ${ }^{17,19}$. This analysis had two

408 parts. First, we used the combined dataset of all stems to test how the effect of herbivory on

409 height of individual stems differed by sampling method. Specifically, we tested for an interactive

410 effect of herbivory ( $1=$ browsed; $0=$ not browsed $)$ and sampling method on log-transformed

411 stem height using mixed-effects linear regression models. We specified stand identity and year as

412 crossed random intercepts, used likelihood ratio tests to compare models with and without an 
413 herbivory $\times$ sampling method interaction, computed population-averaged fitted values from the

414 model including the herbivory $\times$ sampling method interaction (Fig. 3E), and used this model to

415 calculate differences in the effect of herbivory on stem height between 5T stems and random

416 stems. Second, we examined how the relationship between annual estimates of average stem

417 height and browse probability differed between 5T stems and random stems (Fig. 3E). These

418 annual estimates were the fitted values of mixed-effect models of herbivory and stem height that

419 specified year as a categorical variable (Fig. 3, A and B). We used simple linear regression to

420 compute the coefficient of determination for each relationship.

$421 \quad$ Finally, we assessed how selective sampling of 5T stems together with different

422 assumptions about browse escape height influenced estimates of regeneration of overstory aspen

423 stems. Following previous studies ${ }^{15,16,18,20}$, we measured regeneration of overstory stems as the

424 percentage of sampled aspen stands that showed evidence of stems taller than the presumed

425 reach of elk. Specifically, we measured the annual percentage of sampled aspen stands in which

426 the mean height of 5T stems and randomly sampled stems exceeded a presumed browse-escape

427 height of $200-\mathrm{cm}$ or $300-\mathrm{cm}$ (Fig. 4).

428

429 Data Availability: Data are archived in Dryad (\#\#).

$431 \quad$ Methods References

432 38. Houston, D. G. The northern Yellowstone elk: ecology and management. (Macmillan, 1982).

433 39. Tallian, A. et al. Predator foraging response to a resurgent dangerous prey. Functional

$434 \quad$ Ecology 31, 1418-1429 (2017). 
40. Bangs, E. E. \& Fritts, S. H. Reintroducing the gray wolf to central Idaho and Yellowstone National Park. Wildlife Society Bulletin 24, 402-413 (1996).

41. Stahler, E. E., Smith, D. W. \& Stahler, D. R. Wolf turf: A glimpse at 20 years of wolf spatial ecology in Yellowstone. Yellowstone Science 24, 50-54 (2016). wolf restoration to Yellowstone National Park. Wildlife Monographs 169, 1-30 (2008).

43. Metz, M. C., Smith, D. W., Vucetich, J. A., Stahler, D. R. \& Peterson, R. O. Seasonal patterns of predation for gray wolves in the multi-prey system of Yellowstone National Park:

44. Ruth, T., Buotte, P. \& Hornocker, M. Yellowstone Cougars: Ecology Before And During Wolf Restoration. (University Press of Colorado, 2019). doi:10.5876/9781607328292. of understanding northern Yellowstone elk dynamics after wolf reintroduction. Yellowstone

46. White, E. P. J., Wallen, R. L. \& Hallac, D. E. Yellowstone Bison: Conserving an American Icon in Modern Society. (Yellowstone Association, 2015).

47. Jones, J. R. \& DeByle, N. V. Climates. in Aspen: Ecology and management in the western United States. USDA Forest Service general technical report RM-119 (eds. DeByle, N. V. \& Winokur, R. P.) 294 (Rocky Mountain Forest Range Experiment Station, 1985).

454 48. Larsen, E. J. \& Ripple, W. J. Aspen age structure in the northern Yellowstone ecosystem: 
49. Mueggler, W. F. Vegetation associations. in Aspen: Ecology and management in the western

Winokur, R. P.) 294 (Rocky Mountain Forest Range Experiment Station, 1985).

50. DeByle, N. V. Wildlife. in Aspen: Ecology and management in the western United States.

$$
\text { P.) } 294 \text { (Rocky Mountain Forest Range Experiment Station, 1985). }
$$

51. National Research Council. Ecological Dynamics on Yellowstone's Northern Range. (The National Academies Press, 2002).

52. Seager, S. T., Eisenberg, C. \& St. Clair, S. B. Patterns and consequences of ungulate (2013).

53. Meagher, M. \& Houston, D. B. Yellowstone and the Biology of Time: Photographs across a Century. (University of Oklahoma Press, 1999).

54. Larsen, E. J. \& Ripple, W. J. Aspen stand conditions on elk winter ranges in the northern Yellowstone, USA. Natural Areas Journal 25, 326 (2005). Management 3, 295-306 (1939).

476 58. Smith, D. W. \& Tyers, D. B. The history and current status and distribution of beavers in 477 Yellowstone National Park. Northwest Science 86, 276 (2012). 
59. Yellowstone National Park. Yellowstone's northern range : complexity \& change in a wildland ecosystem. 164 (1997).

60. Singer, F. J., Swift, D. M., Coughenour, M. B. \& Varley, J. D. Thunder on the Yellowstone revisited: An assessment of management of native ungulates by natural regulation, 19681993. Wildlife Society Bulletin 26, 17 (1998).

61. Kay, C. Yellowstone's Northern elk herd: a critical evaluation of the 'natural regulation' paradigm. (Utah State University Logan, 1990).

62. Wagner, F. H. Yellowstone’s Destabilized Ecosystem: Elk Effects, Science, and Policy

63. Romme, W. H., Turner, M. G., Wallace, L. L. \& Walker, J. S. Aspen, elk, and fire in northern Yellowstone Park. Ecology 76, 2097-2106 (1995). national parks of North America. Wildlife Society Bulletin 26, 449-462 (1998).

65. Ripple, W. J. \& Larsen, E. J. Historic aspen recruitment, elk, and wolves in northern

66. Piekielek, N. B., Hansen, A. J. \& Chang, T. Using custom scientific workflow software and GIS to inform protected area climate adaptation planning in the Greater Yellowstone Ecosystem. Ecological Informatics 30, 40-48 (2015). Theory and Methods 13, 433-484 (1984).

68. Seber, G. A. F. \& Wild, C. J. Nonlinear regression. (John Wiley and Sons, 2003). doi:10.1002/0471725315.fmatter. 
bioRxiv preprint doi: https://doi.org/10.1101/2020.05.05.079459; this version posted May 7, 2020. The copyright holder for this preprint (which was not certified by peer review) is the author/funder, who has granted bioRxiv a license to display the preprint in perpetuity. It is made available under aCC-BY-NC-ND 4.0 International license.

69. Burnham, K. P. \& Anderson, D. R. Model Selection and Multi-model Inference: A Practical 
502 Acknowledgements: We thank R. Renkin and J. Klaptosky for administrative and field

503 assistance. We acknowledge support from the U.S. National Science Foundation (DGE-

504 1633756), University of Wyoming-National Park Service Small Grant Program (1003867-USU),

505 Yellowstone National Park, and Utah State University.

506 Author contributions: E.M.B., E.J.L., D.R.M. conceived and designed the study; E.J.L.

507 collected most of the data; E.M.B. and D.R.M. analyzed the data and wrote the manuscript with

508 input from E.J.L.

509 Competing interests: The authors declare no competing interests.

510 Additional Information:

511 Extended Data is available for this paper.

512 Supplementary Information is available for this paper.

513 Correspondence and requests for materials should be addressed to E.M.B.

514 (elbrice92@gmail.com). 


\section{Extended Data}

516 Extended Data Table 1. Refereed articles showing annual trends in height and (or) herbivory of

517 young aspen in Yellowstone National Park attributed to the cascading effects of wolves. Number

518 of the article cited in the main text (Ref.), number of the relevant data figure in the cited article

519 (Fig.), source of data shown in relevant data figure (Data Source), timespan covered by the data

520 (Data Years), type of data collected (Height, Herbivory), and method of data collection (selective

521 sampling of the five tallest young aspen [Five Tallest] or random sampling of all young aspen

522 [Random]) are given for each article. Checkmarks indicate which data were collected and with

523 which sampling method. Shaded cells indicate articles that reproduced data originating from

524 Ripple and Beschta (2007), and dashed-outlined cells indicate articles that reproduced data

525 originating from Painter et al. (2014). Underlined data in Peterson et al. (2014) were unpublished

526 data from E. Larsen, some of which were the subject of the current analysis.

\begin{tabular}{|c|c|c|c|c|c|c|c|c|}
\hline \multirow[b]{2}{*}{$\begin{array}{l}\text { Authors } \\
\text { (Year) }\end{array}$} & \multirow[b]{2}{*}{ Ref. } & \multirow[b]{2}{*}{ Fig. } & \multirow[b]{2}{*}{ Data Source } & \multirow[b]{2}{*}{ Data Years } & \multicolumn{2}{|c|}{ Data Type } & \multicolumn{2}{|c|}{ Sampling Method } \\
\hline & & & & & Height & Herbivory & $\begin{array}{c}\text { Five } \\
\text { Tallest }\end{array}$ & Random \\
\hline $\begin{array}{l}\text { Ripple \& } \\
\text { Beschta } \\
\text { (2007) }\end{array}$ & 11 & $1 \mathrm{c}-\mathrm{d}$ & $\begin{array}{l}\text { Original data (98 } \\
\text { stands) }\end{array}$ & $1998-2006$ & $\checkmark$ & $\checkmark$ & $\checkmark$ & \\
\hline $\begin{array}{l}\text { Beschta \& } \\
\text { Ripple (2009) }\end{array}$ & 13 & $8 b$ & $\begin{array}{l}\text { Ripple \& Beschta } \\
(2007)\end{array}$ & $1999-2005$ & $\checkmark$ & $\checkmark$ & $\checkmark$ & \\
\hline $\begin{array}{l}\text { Ripple \& } \\
\text { Beschta } \\
(2012)\end{array}$ & 14 & $1 c-d$ & $\begin{array}{l}\text { Ripple \& Bestchta } \\
(2007) \\
\text { Original data } \\
\text { (resampled } 98 \\
\text { stands) }\end{array}$ & $\begin{array}{l}1998-2006 \\
2010\end{array}$ & $\checkmark$ & $\checkmark$ & $\checkmark$ & \\
\hline $\begin{array}{l}\text { Beschta \& } \\
\text { Ripple (2016) }\end{array}$ & 17 & $3 g$ & $\begin{array}{l}\text { Ripple \& Bestchta } \\
(2007,2012)\end{array}$ & $\begin{array}{l}1998-2006, \\
2010\end{array}$ & $\checkmark$ & & $\checkmark$ & \\
\hline $\begin{array}{l}\text { Beschta et al. } \\
(2018)\end{array}$ & 19 & $2 b-c$ & $\begin{array}{l}\text { Ripple \& Bestchta } \\
\text { (2007, 2012) } \\
\text { Original data (60 } \\
\text { additional stands) }\end{array}$ & $\begin{array}{l}1999-2006, \\
2010 \\
2005-2015\end{array}$ & $\checkmark$ & $\checkmark$ & $\checkmark$ & \\
\hline
\end{tabular}




\section{Extended Data Table 1 continued}

\begin{tabular}{|c|c|c|c|c|c|c|c|c|}
\hline \multirow[b]{2}{*}{$\begin{array}{l}\text { Authors } \\
\text { (Year) }\end{array}$} & \multirow[b]{2}{*}{ Ref. } & \multirow[b]{2}{*}{ Fig. } & \multirow[b]{2}{*}{ Data Source } & \multirow[b]{2}{*}{ Data Years } & \multicolumn{2}{|c|}{ Data Type } & \multicolumn{2}{|c|}{ Sampling Method } \\
\hline & & & & & Height & Herbivory & $\begin{array}{l}\text { Five } \\
\text { Tallest }\end{array}$ & Random \\
\hline
\end{tabular}

\begin{tabular}{|c|c|c|c|c|c|c|c|c|}
\hline $\begin{array}{l}\text { Painter et al. } \\
(2014)^{1}\end{array}$ & 15 & $7 \mathrm{a}$ & $\begin{array}{l}\text { Original data ( } 87 \\
\text { stands) }\end{array}$ & $2003-2012$ & $\checkmark$ & $\checkmark$ & $\checkmark$ & \\
\hline $\begin{array}{l}\text { Peterson et al. } \\
\text { (2014) }\end{array}$ & 10 & $1 \mathrm{c}$ & $\begin{array}{l}\text { Painter et al. (2014) } \\
\text { Original data (113 } \\
\underline{\text { stands) }}\end{array}$ & $\begin{array}{l}2003-2012 \\
1999-2013^{2}\end{array}$ & $\checkmark$ & & $\checkmark$ & $\checkmark$ \\
\hline $\begin{array}{l}\text { Painter et al. } \\
(2015)^{1}\end{array}$ & 16 & $2 \mathrm{a}$ & Painter et al. (2014) & 2003-2012 & $\checkmark$ & & $\checkmark$ & \\
\hline $\begin{array}{l}\text { Beschta et al. } \\
(2016)\end{array}$ & 18 & $5 c$ & Painter et al. (2014) & $2002^{3}-2012$ & & $\checkmark$ & $\checkmark$ & \\
\hline $\begin{array}{l}\text { Painter et al. } \\
(2018)^{1} \\
\end{array}$ & 20 & $3 a$ & $\begin{array}{l}\text { Ripple \& Bestchta } \\
(2007,2012) \\
\text { Painter et al. (2014) }\end{array}$ & $\begin{array}{l}1999-2006, \\
2010 \\
2005-2012\end{array}$ & & $\checkmark$ & $\checkmark$ & \\
\hline $\begin{array}{l}\text { Halofsky et } \\
\text { al. }(2008)^{4}\end{array}$ & 12 & $3 a-b$ & $\begin{array}{l}\text { Original data (44 } \\
\text { stands) }\end{array}$ & $1995-2004$ & $\checkmark$ & $\checkmark$ & $\checkmark$ & \\
\hline
\end{tabular}

527 Included data from a random sample of young aspen in Yellowstone National Park that provided no

528 information on annual trends in height, and little or no information on annual trends in herbivory. The

529 latter was limited to changes in herbivory during 1997-1998 and 2011-2012 reported in Painter et al.

$530 \quad(2014,2015)$.

$531 \quad 2$ No data for 2000 and 2003

$532{ }^{3}$ Source of 2002 data was not specified.

$533{ }^{4}$ Sampled the three tallest young aspen within a stand. 
534 Extended Data Table 2. Model selection results for GLMMs describing the effect of stem

535 height (ht) on the probability that a "five tallest" young aspen was browsed in northern

536 Yellowstone National Park. Variables ht1 and ht 2 contain a linear spline at the indicated knot

537 (cm). The intercept and simple linear models included no knot. All models included random

538 effects for stand identity and year. Log-likelihood $(\mathrm{LL})$, number of parameters $(K), \mathrm{AIC}_{\mathrm{c}}$,

539 differences in $\mathrm{AIC}_{\mathrm{c}}$ compared to the best scoring model $\left(\triangle \mathrm{AIC} \mathrm{C}_{\mathrm{c}}\right)$, and $\mathrm{AIC}_{\mathrm{c}}$ weights $(W)$ are

540 given for each model. The best model $\left(\Delta \mathrm{AIC}_{\mathrm{c}}=0.00\right)$ is in boldface and competitive models

$541 \quad\left(\Delta \mathrm{AIC}_{\mathrm{c}}<2.00\right)$ are shaded.

\begin{tabular}{lrrrrrr}
\hline Model & Knot $(\mathrm{cm})$ & $\mathrm{LL}$ & $K$ & $\mathrm{AIC}_{\mathrm{c}}$ & $\Delta \mathrm{AIC}_{\mathrm{c}}$ & $W$ \\
\hline intercept & - & -2166.41 & 3 & 4339.04 & 749.59 & 0.00 \\
ht & - & -1845.00 & 4 & 3698.36 & 108.92 & 0.00 \\
ht1, ht2 & 10 & -1845.00 & 5 & 3700.55 & 111.11 & 0.00 \\
ht1, ht2 & 20 & -1839.17 & 5 & 3688.90 & 99.46 & 0.00 \\
ht1, ht2 & 30 & -1830.38 & 5 & 3671.32 & 81.87 & 0.00 \\
ht1, ht2 & 40 & -1822.30 & 5 & 3655.16 & 65.72 & 0.00 \\
ht1, ht2 & 50 & -1817.03 & 5 & 3644.62 & 55.17 & 0.00 \\
ht1, ht2 & 60 & -1813.72 & 5 & 3638.01 & 48.56 & 0.00 \\
ht1, ht2 & 70 & -1810.72 & 5 & 3632.01 & 42.57 & 0.00 \\
ht1, ht2 & 80 & -1808.52 & 5 & 3627.60 & 38.16 & 0.00 \\
ht1, ht2 & 90 & -1802.95 & 5 & 3616.47 & 27.03 & 0.00 \\
ht1, ht2 & 100 & -1797.70 & 5 & 3605.96 & 16.52 & 0.00 \\
ht1, ht2 & 110 & -1793.95 & 5 & 3598.46 & 9.01 & 0.00 \\
ht1, ht2 & 111 & -1793.71 & 5 & 3597.98 & 8.54 & 0.00 \\
ht1, ht2 & 112 & -1793.46 & 5 & 3597.48 & 8.04 & 0.00 \\
ht1, ht2 & 113 & -1793.19 & 5 & 3596.94 & 7.49 & 0.00 \\
ht1, ht2 & 114 & -1792.95 & 5 & 3596.47 & 7.03 & 0.00 \\
ht1, ht2 & 115 & -1792.75 & 5 & 3596.07 & 6.62 & 0.00
\end{tabular}


Extended Data Table 2 continued

\begin{tabular}{|c|c|c|c|c|c|c|}
\hline Model & Knot $(\mathrm{cm})$ & $\mathrm{LL}$ & $K$ & $\mathrm{AIC}_{\mathrm{c}}$ & $\Delta \mathrm{AIC}_{\mathrm{c}}$ & $W$ \\
\hline ht1, ht2 & 116 & -1792.61 & 5 & 3595.78 & 6.34 & 0.00 \\
\hline ht1, ht2 & 117 & -1792.47 & 5 & 3595.51 & 6.07 & 0.00 \\
\hline ht1, ht2 & 118 & -1792.36 & 5 & 3595.27 & 5.83 & 0.00 \\
\hline ht1, ht2 & 119 & -1792.17 & 5 & 3594.91 & 5.47 & 0.01 \\
\hline ht1, ht2 & 120 & -1792.02 & 5 & 3594.59 & 5.15 & 0.01 \\
\hline ht1, ht2 & 121 & -1791.77 & 5 & 3594.11 & 4.67 & 0.01 \\
\hline ht1, ht2 & 122 & -1791.53 & 5 & 3593.62 & 4.18 & 0.01 \\
\hline ht1, ht2 & 123 & -1791.28 & 5 & 3593.12 & 3.67 & 0.01 \\
\hline ht1, ht2 & 124 & -1791.06 & 5 & 3592.68 & 3.24 & 0.02 \\
\hline ht1, ht2 & 125 & -1790.89 & 5 & 3592.33 & 2.89 & 0.02 \\
\hline ht1, ht2 & 126 & -1790.57 & 5 & 3591.69 & 2.25 & 0.03 \\
\hline ht1, ht2 & 127 & -1790.27 & 5 & 3591.10 & 1.66 & 0.03 \\
\hline ht1, ht2 & 128 & -1789.96 & 5 & 3590.49 & 1.04 & 0.05 \\
\hline ht1, ht2 & 129 & -1789.70 & 5 & 3589.97 & 0.52 & 0.06 \\
\hline ht1, ht2 & 130 & -1789.53 & 5 & 3589.63 & 0.18 & 0.07 \\
\hline ht1, ht2 & 131 & -1789.47 & 5 & 3589.51 & 0.06 & 0.07 \\
\hline ht1, ht2 & 132 & -1789.44 & 5 & 3589.44 & 0.00 & 0.08 \\
\hline ht1, ht2 & 133 & -1789.48 & 5 & 3589.51 & 0.07 & 0.07 \\
\hline ht1, ht2 & 134 & -1789.52 & 5 & 3589.61 & 0.16 & 0.07 \\
\hline $\mathrm{ht} 1, \mathrm{ht} 2$ & 135 & -1789.61 & 5 & 3589.77 & 0.33 & 0.07 \\
\hline ht1, ht2 & 136 & -1789.65 & 5 & 3589.86 & 0.41 & 0.06 \\
\hline ht1, ht2 & 137 & -1789.75 & 5 & 3590.06 & 0.61 & 0.06 \\
\hline ht1, ht2 & 138 & -1789.89 & 5 & 3590.35 & 0.90 & 0.05 \\
\hline ht1, ht2 & 139 & -1790.07 & 5 & 3590.71 & 1.26 & 0.04 \\
\hline ht1, ht2 & 140 & -1790.33 & 5 & 3591.23 & 1.79 & 0.03 \\
\hline ht1, ht2 & 141 & -1790.66 & 5 & 3591.88 & 2.44 & 0.02 \\
\hline ht1, ht2 & 142 & -1791.00 & 5 & 3592.56 & 3.11 & 0.02 \\
\hline
\end{tabular}


Extended Data Table 2 continued

542

\begin{tabular}{lrrrrrr}
\hline Model & Knot $(\mathrm{cm})$ & $\mathrm{LL}$ & $K$ & $\mathrm{AIC}_{\mathrm{c}}$ & $\Delta \mathrm{AIC}_{\mathrm{c}}$ & $W$ \\
\hline ht1, ht2 & 143 & -1791.37 & 5 & 3593.31 & 3.86 & 0.01 \\
ht1, ht2 & 144 & -1791.85 & 5 & 3594.25 & 4.81 & 0.01 \\
ht1, ht2 & 145 & -1792.34 & 5 & 3595.23 & 5.79 & 0.00 \\
ht1, ht2 & 146 & -1792.80 & 5 & 3596.15 & 6.71 & 0.00 \\
ht1, ht2 & 147 & -1793.25 & 5 & 3597.06 & 7.62 & 0.00 \\
ht1, ht2 & 148 & -1793.70 & 5 & 3597.97 & 8.53 & 0.00 \\
ht1, ht2 & 149 & -1794.21 & 5 & 3598.98 & 9.54 & 0.00 \\
ht1, ht2 & 150 & -1794.70 & 5 & 3599.97 & 10.53 & 0.00 \\
ht1, ht2 & 160 & -1799.25 & 5 & 3609.06 & 19.62 & 0.00 \\
ht1, ht2 & 170 & -1803.13 & 5 & 3616.83 & 27.39 & 0.00 \\
ht1, ht2 & 180 & -1807.42 & 5 & 3625.39 & 35.95 & 0.00 \\
ht1, ht2 & 190 & -1811.10 & 5 & 3632.77 & 43.33 & 0.00 \\
ht1, ht2 & 200 & -1813.79 & 5 & 3638.13 & 48.69 & 0.00 \\
\hline
\end{tabular}


543 Extended Data Table 3. Model selection results for GLMMs describing the effect of stem

544 height (ht) on the probability that a randomly sampled young aspen was browsed in northern

545 Yellowstone National Park. Variables ht1 and ht2 contain a linear spline at the indicated knot

546 (cm). The intercept and simple linear models included no knot. All models included random

547 effects for stand identity and year. Log-likelihood $(\mathrm{LL})$, number of parameters $(K), \mathrm{AIC}_{\mathrm{c}}$,

548 differences in $\mathrm{AIC}_{\mathrm{c}}$ compared to the best scoring model $\left(\triangle \mathrm{AIC}_{\mathrm{c}}\right)$, and $\mathrm{AIC}_{\mathrm{c}}$ weights $(W)$ are

549 given for each model. The best model $\left(\Delta \mathrm{AIC}_{\mathrm{c}}=0.00\right)$ is in boldface and competitive models

$550 \quad\left(\Delta \mathrm{AIC}_{\mathrm{c}}<2.00\right)$ are shaded.

\begin{tabular}{lrrrrrr}
\hline Model & Knot $(\mathrm{cm})$ & $\mathrm{LL}$ & $K$ & $\mathrm{AIC}_{\mathrm{c}}$ & $\Delta \mathrm{AIC}_{\mathrm{c}}$ & $W$ \\
\hline intercept & - & -8238.90 & 3 & 16484.05 & 1028.55 & 0.00 \\
ht & - & -7886.08 & 4 & 15780.57 & 325.08 & 0.00 \\
ht1, ht2 & 10 & -7885.74 & 5 & 15782.08 & 326.59 & 0.00 \\
ht1, ht2 & 20 & -7886.00 & 5 & 15782.60 & 327.11 & 0.00 \\
ht1, ht2 & 30 & -7883.24 & 5 & 15777.08 & 321.58 & 0.00 \\
ht1, ht2 & 40 & -7877.04 & 5 & 15764.69 & 309.20 & 0.00 \\
ht1, ht2 & 50 & -7859.22 & 5 & 15729.05 & 273.56 & 0.00 \\
ht1, ht2 & 60 & -7835.44 & 5 & 15681.48 & 225.99 & 0.00 \\
ht1, ht2 & 70 & -7803.77 & 5 & 15618.14 & 162.65 & 0.00 \\
ht1, ht2 & 80 & -7776.04 & 5 & 15562.69 & 107.19 & 0.00 \\
ht1, ht2 & 90 & -7755.96 & 5 & 15522.53 & 67.04 & 0.00 \\
ht1, ht2 & 100 & -7738.23 & 5 & 15487.07 & 31.58 & 0.00 \\
ht1, ht2 & 110 & -7726.73 & 5 & 15464.07 & 8.58 & 0.00 \\
ht1, ht2 & 111 & -7726.10 & 5 & 15462.81 & 7.32 & 0.00 \\
ht1, ht2 & 112 & -7725.49 & 5 & 15461.59 & 6.10 & 0.00 \\
ht1, ht2 & 113 & -7724.91 & 5 & 15460.43 & 4.94 & 0.01 \\
ht1, ht2 & 114 & -7724.41 & 5 & 15459.43 & 3.94 & 0.01 \\
ht1, ht2 & 115 & -7724.08 & 5 & 15458.78 & 3.28 & 0.02
\end{tabular}


Extended Data Table 3 continued

\begin{tabular}{|c|c|c|c|c|c|c|}
\hline Model & Knot $(\mathrm{cm})$ & $\mathrm{LL}$ & $K$ & $\mathrm{AIC}_{\mathrm{c}}$ & $\Delta \mathrm{AIC}_{\mathrm{c}}$ & $W$ \\
\hline ht1, ht2 & 116 & -7723.73 & 5 & 15458.07 & 2.58 & 0.03 \\
\hline ht1, ht2 & 117 & -7723.49 & 5 & 15457.58 & 2.08 & 0.03 \\
\hline ht1, ht2 & 118 & -7723.15 & 5 & 15456.91 & 1.42 & 0.05 \\
\hline ht1, ht2 & 119 & -7722.91 & 5 & 15456.43 & 0.94 & 0.06 \\
\hline ht1, ht2 & 120 & -7722.62 & 5 & 15455.85 & 0.35 & 0.08 \\
\hline ht1, ht2 & 121 & -7722.51 & 5 & 15455.63 & 0.14 & 0.09 \\
\hline ht1, ht2 & 122 & -7722.44 & 5 & 15455.49 & 0.00 & 0.09 \\
\hline ht1, ht2 & 123 & -7722.47 & 5 & 15455.54 & 0.05 & 0.09 \\
\hline ht1, ht2 & 124 & -7722.55 & 5 & 15455.70 & 0.20 & 0.08 \\
\hline ht1, ht2 & 125 & -7722.68 & 5 & 15455.97 & 0.47 & 0.07 \\
\hline ht1, ht2 & 126 & -7722.81 & 5 & 15456.22 & 0.73 & 0.06 \\
\hline ht1, ht2 & 127 & -7722.99 & 5 & 15456.58 & 1.09 & 0.05 \\
\hline ht1, ht2 & 128 & -7723.19 & 5 & 15456.98 & 1.49 & 0.04 \\
\hline ht1, ht2 & 129 & -7723.39 & 5 & 15457.39 & 1.90 & 0.04 \\
\hline ht1, ht2 & 130 & -7723.66 & 5 & 15457.92 & 2.42 & 0.03 \\
\hline ht1, ht2 & 131 & -7723.99 & 5 & 15458.60 & 3.10 & 0.02 \\
\hline ht1, ht2 & 132 & -7724.36 & 5 & 15459.33 & 3.84 & 0.01 \\
\hline $\mathrm{ht} 1, \mathrm{ht} 2$ & 133 & -7724.81 & 5 & 15460.24 & 4.74 & 0.01 \\
\hline ht1, ht2 & 134 & -7725.26 & 5 & 15461.12 & 5.63 & 0.01 \\
\hline ht1, ht2 & 135 & -7725.81 & 5 & 15462.22 & 6.72 & 0.00 \\
\hline ht1, ht2 & 136 & -7726.37 & 5 & 15463.35 & 7.86 & 0.00 \\
\hline ht1, ht2 & 137 & -7727.03 & 5 & 15464.66 & 9.17 & 0.00 \\
\hline ht1, ht2 & 138 & -7727.75 & 5 & 15466.11 & 10.62 & 0.00 \\
\hline ht1, ht2 & 139 & -7728.53 & 5 & 15467.68 & 12.18 & 0.00 \\
\hline ht1, ht2 & 140 & -7729.36 & 5 & 15469.33 & 13.84 & 0.00 \\
\hline ht1, ht2 & 141 & -7730.18 & 5 & 15470.96 & 15.47 & 0.00 \\
\hline ht1, ht2 & 142 & -7731.08 & 5 & 15472.76 & 17.27 & 0.00 \\
\hline
\end{tabular}


Extended Data Table 3 continued

\begin{tabular}{|c|c|c|c|c|c|c|}
\hline Model & Knot $(\mathrm{cm})$ & $\mathrm{LL}$ & $K$ & $\overline{\mathrm{AIC}_{\mathrm{c}}}$ & $\Delta \mathrm{AIC}_{\mathrm{c}}$ & $55 D$ \\
\hline ht1, ht2 & 143 & -7732.01 & 5 & 15474.64 & 19.14 & 05030 \\
\hline ht1, ht2 & 144 & -7733.11 & 5 & 15476.82 & 21.33 & 9590 \\
\hline ht1, ht2 & 145 & -7734.31 & 5 & 15479.23 & 23.74 & 0.00 \\
\hline ht1, ht2 & 146 & -7735.54 & 5 & 15481.68 & 26.19 & 0.00 \\
\hline ht1, ht2 & 147 & -7736.72 & 5 & 15484.05 & 28.56 & 0.00 \\
\hline ht1, ht2 & 148 & -7737.86 & 5 & 15486.32 & 30.83 & 0.00 \\
\hline ht1, ht2 & 149 & -7739.02 & 5 & 15488.64 & 33.15 & 0.00 \\
\hline ht1, ht2 & 150 & -7740.22 & 5 & 15491.05 & 35.56 & 0.00 \\
\hline ht1, ht2 & 160 & -7749.68 & 5 & 15509.98 & 54.48 & 0.00 \\
\hline ht1, ht2 & 170 & -7760.17 & 5 & 15530.95 & 75.46 & 0.00 \\
\hline ht1, ht2 & 180 & -7771.68 & 5 & 15553.96 & 98.47 & 0.00 \\
\hline ht1, ht2 & 190 & -7781.88 & 5 & 15574.36 & 118.86 & 0.00 \\
\hline ht1, ht2 & 200 & -7793.35 & 5 & 15597.31 & 141.82 & 0.00 \\
\hline
\end{tabular}

